\title{
右半球における漢字と仮名の意味処理機能
}

\author{
福岡教育大学 永 江 誠 司
}

Semantic processing functions of Kanji and Kana words in the right hemisphere

Seiji Nagae (Department of Psychology, Faculty of Education,
Fukuoka University of Education, Akama, Munakata 811-41)

The purpose of this experiment was to investigate the semantic processing of words written in Kanji and Kana in the normal right cerebral hemisphere of the brain. The sentence judgement task required subjects to judge whether the laterally presented word written in Kanji or Kana was congruous with the meaning of the sentence which was presented prior to the sentence judgement task. Concrete and abstract words were employed in the experiment. A manual reaction time measure was used to assess the relative efficiency of lateral stimulus-response pathways in processing linguistic information. Results showed that the subjects significantly judged the concrete words written in Kanji or Kana faster than abstract words when they were presented in the left visual field; there were no significant reaction time differences in the judgement of both concrete and abstract words presented in the right visual field. These results were interpreted as supporting the view that the right hemisphere of the brain can play a functional role in processing words to some degree.

Key words: right hemisphere, sentence judgement task, semantic processing, Kanji, Kana, concreteness, intact brain.

本実験の目的は，漢字と仮名を用いた文適合判断課 題(sentence judgement task)に視野分割提示法を導入 することにより，漢字と仮名の意味処理過程で右半球 がどのような役割を果たしているのかについて検討す るところにある. 右半球の言語処理機能力について は, 神経心理学領域において臨床研究と実験研究の両 面から検討されてきており,この領域の重要な論点の 一つとなっている(Joanette, Goulet, \& Hannequin, 1990)。脳損傷患者を対象とした臨床研究からは, 語 の処理の中でも抽象語の処理は左半球優位であるが, 具象語の処理は半球差のみられないことが示されてい る.ここから, 右半球が語の処理の中で具象語の処理 にある程度関与していることが示唆されている (Gainotti, Caltagirone, Miceli, \& Masullo, 1981; Kinsbourne, 1971; Lesser, 1974 ; Shallice \& Warrington, 1975)。しかしながら，これらの研究で 被験者となった患者はそれぞれ固有の神経学的な病歴 をもっていること, また同一の患者でも結果に変動の みられることなどから (Gazzaniga, Volpe, Smylie, Wilson, \& LeDoux, 1979), 先の指摘を直ちに一般化 していくことに慎重論も出されている(Code, 1987). したがって, 健常者を対象とした実験研究を行うこと
により，臨床研究の指摘した見解を確かめてみること は意義あることであろう。

正常な右半球がどのような言語の処理能力をもって いるかについては, 語の具象性やイメージ可能性を操 作した視野分割実験によって重要な知見が提供されて きている.しかし,これまでのところそれらの研究 は，やや矛盾した結果を報告している。まず，Ellis＆ Shepherd (1974) は具象語と抽象語を左右視野に同時 提示し，それらの語の音読による再生 (同定判断) を求 めている。 その結果, 具象語, 抽象語ともに右視野優 位であることを見出しているが，左視野では具象語が 抽象語より有意に再生のよいことを指摘している。こ のことから具象語は両半球で表象されうると仮定し, その理由を具象語は発達的に早く習得され, またイメ ージ価も高いことから心像化能力の高い右半球でもそ の処理が可能なのだと説明している. しかし, Ellis \& Shepherd (1974)の追試を行った Orenstein \& Meighan (1976)の研究では,この結果は検証されていない. さ らに，具象語あるいは抽象語を片側視野に提示して語 の再生を求めた Bradshaw \& Gates（1978）の実験 3 で は, 抽象語, 具象語ともに右視野優位であったが, 左 視野での具象語の優位は Ellis \& Shepherd (1974) と同 
じようには得られなかった。そこから，これらの語の 処理が具象性にかかわらず, ともに左半球に特殊化さ れていることを示唆している.

また, Day（1977) は語の真偽判断を求める課題 (語 彙判断課題)において, 抽象語は右視野優位であるが 具象語は視野差のないことを報告している(実験 1 ). これは, 右半球の言語処理が語の具象性によっては可 能であることを示している. 同じ結果は, 同様に語彙 判断課題を用いた Mannhaupt（1983）でも報告されて いる.しかし, Day (1977)の実験をほほ追試した

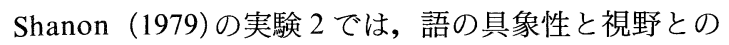
交互作用は見出されていない.さらに, Day (1977) は実験 2 で片側視野に提示された具象語あるいは抽象 語が, 事前に提示されていた上位の意味カテゴリーに 属するかどうかの判断(カテゴリー判断)を求めてい る. その結果, 抽象語は右視野優位であるが具象語は 視野差のないことを示している.この結果は, 上位力 テゴリー語を視野中央に, 具象語あるいは抽象語を片 側視野に同時提示した実験 3 でも確認されている。こ こから, 抽象語のカテゴリー判断は左半球で容易に遂 行され, 具象語のそれは右半球が左半球と同じ程度に 遂行できると説明されている.これは, いわゆる右半 球の心像化能力の優位性を仮定した右半球心像化説 (right hemisphere imageability hypothesis)を支持する 見解とみることができるだろう(Code， 1987). Day (1977) の実験 2 と実験 3 の結果は, 語のカテゴリー判 断という意味的処理を求める課題で, 語の具象性によ っては右半球の関与が認められることを示している点 で注目される。

以上のように, 右半球における言語の処理能力に関 しては, 語の具象性を操作した諸実験で一義的な結果 が得られないままになっているといえよう. Boles (1983)が指摘しているように, これらの実験で用いら れた刺激の提示位置 (片側と両側), 提示方向 (水平と 垂直), 語の種類 (英語と非英語), そして従属変数 (正 答数と反応時間) などの諸変数は, それぞれ具象性と 視野の交互作用に影響を及ぼす場合とそうでない場合 があり，これらの変数から具象性の視野効果を説明す ることは難しい. ただ, 課題として語の同定判断や語 彙判断を用いた実験で比較的矛盾した結果がみられる のに対し,Day（1977）の実験 2 と実験 3 で語のカテ ゴリー判断を求めたときに，より明瞭な具象性の視野 効果がみられたことは注目される。このことは, 具象 性の視野効果が語の意味処理を必要とするときに出現 する可能性の高いことを示唆していると考えられる.

ところで, 漢字と仮名の視野優位性に関する研究で は, 仮名が右視野優位でほぼ安定した結果を得ている のに対し, 漢字は一定した結果を示していない. 漢字
処理の大脳半球特殊化については, 総括的な論評がい くつか出されているが(永江, 1989, 1991，1992; Paradis, Hagiwara, \& Hildebrandt, 1985 ; 島田・大塚, 1981 など), 抢おむね左半球への特殊化の優位なこと が示唆されている.ただ, 漢字の意味処理については 右半球関与の可能性が指摘されている.これまで議論 してきた漢字の具象性を操作した視野分割実験では, Hatta (1977), Ohnishi \& Hatta (1980), Hayashi \& Hatta（1982）において漢字の具象性と視野との交互作 用は見出されていない.これらの実験では, 刺激は 1 字漢字, 提示は片側と両側, 従属変数は正答 (誤答) 数 と反応時間, そして課題は同定判断とカテゴリー判断 を用いている。ただ, Hayashi \& Hatta (1982)が用い たカテゴリー判断は, 片側視野に提示された語のカテ ゴリーを予め用意されている 3 つのカテゴリー(例え ば, 動物, 植物, 体の一部) の中からボタン押し反応 によって選択するものであり, Day (1977)のカテゴ リー判断と同一のものではない.

これらの実験に対し, Elman, Takahashi，\& Tohsaku（1981）は高具象漢字で視野差なし, 低具象 漢字で右視野優位の結果を報告している.これは, 右 半球の漢字処理能力が語の具象性によって可能である ことを示唆している. 彼らの実験では, 刺激は 1 字漢 字, 提示は片側, 従属変数は反応時間, そして課題は 同定判断を用いているので, Hatta（1977）らの実験と 操作手続き上で本質的な相違はないといえるのではな かろうか.これらのことから, 英語を刺激とした実験 と同様に，漢字を刺激とした実験でも具象性の視野効 果については一致した結果が得られないままになって いるといえよう。

以上の議論から, 本実験では漢字と仮名の具象性を 操作し, 語と文の意味的適合性を判断させる課題を用 いることによって, 語認知の視野優位性について検討 する. そこから, 右半球の言語処理が語の具象性によ って可能かどうか，またそれは漢字と仮名で異なるか どうかについて考察する. 実験課題は, 知覚された漢 字と仮名刺激が予め提示されていた文と意味的に適合 するかどうかの判断を求めるものである. したがっ て, その判断はDay（1977)の語のカテゴリー判断を 求める課題よりもより高次の意味処理過程にかかわっ ているといえる。この文適合判断課題を視野分割実験 と組み合せた研究はこれまでないが，この課題を用い ることによって被験者はより高次な意味判断を求めら れることになり，そのような条件下では語の具象性と 視野の交互作用がより明瞭な形で現れるのではないか と考えられる.さらに, 文適合判断課題は元々音韻的 符号化, 形態的符号化, 二重符号化など, 語の符号化 過程を検討するために用いられてきたものである(御 
領，1987；齋藤，1981).したがって，本実験では漢 字と仮名の符号化過程の違いに関しても併せて考察し てみたい.

\section{方 法}

実験計画 語の表記形態として漢字と仮名，語の具 象性として高具象性と低具象性, 語と文の意味的適合 性として適合と不適合, 視野として左視野と右視野の $2 \times 2 \times 2 \times 2$ の要因配置を用いた。これらのうち，表 記形態が被験者間要因, 具象性, 適合性, 視野が被験 者内要因であった。

被験者 Annett (1967)の利き手検査によって, 強 い右手利きと判定された大学生 32 名 (男子 16 名, 女 子 16 名)を被験者として用いた。これらの被験者は, すべて裸眼視力が 1.0 以上のものであった.

刺激材料 漢字材料は, 小川・稲村 (1974)によって 具象性 (concreteness) が測定されている漢字 2 字熟語 の中から, 読みが 3 音節で具象性の高い 40 熟語(平均 具象性 $=5.59, S D=0.66$ ), 具象性の低い 40 熟語(平 均具象性 $=3.25, S D=0.45)$ の計 80 熟語を用いた。高 具象性熟語と低具象性熟語の平均值間の差は有意であ った $(t(78)=18.56, p<.01)$.ここでいう具象性は, 名詞がどの程度具体的な物や人と結びついているかの 評定によって測定されたものである。仮名材料は，用 いた漢字熟語を平仮名表記に改めたものを使用した。 漢字熟語は全て読みが 3 音節なので, 仮名刺激は全て 平仮名 3 文字で表記された。漢字材料は，基準明朝体 (佐藤，1976) を用い, 平仮名材料は中明朝体 (佐藤, 1965)を用いて作製した。片側視野に提示される刺激 材料は, 凝視点から視角にして 3.5 度, 右横かあるい は左横に位置付けた。刺激は漢字, 仮名ともに縦書き とし, 視角 0.6 度 $\times 1.6$ 度の枠内に収まる大きさとし た。

次に，これらの語を目的語とした 80 単文を作成し た。単文は齋藤(1981)にならって，全て“...が…を… する”という表現のものであった，単文の中で，主語 と述語の部分は語で示されているが，“...を”にあた る目的語の部分は空白の枠で示されている. 80 の単 文のうち 40 単文は, 空白の枠内に特定の語を入れる と主語と述語に適合して文意を成す適合文となるもの であり，残りの 40 単文は文意を成さない不適合文と なるものである、不適合文の場合でも, 主語と述語は 必ず呼応しており無意味な文とはなっていない. 全て の単文は縦書きとした。本実験で使用した単文と刺激 語の例は, Table 1 に示したとおりである.

装置 刺激提示は, 3 視野夕キストスコープ(ガー ブランド社製：T-3C) を使って行い, これに接続され た反応潜時記録装置 (トーヨーフィジカル社製)によっ
Table 1

Examples of sentences and words used in the experiment

\begin{tabular}{ll}
\hline Sentence type & Word (Concreteness) \\
\hline Semantically congruent & \\
看護婦が $\square$ を呼ぶ & 医者(High) \\
新聞が $\square$ を伝える & 事実(Low) \\
Semantically incongruent & \\
選手が $\square$ を放棄する & 石油(High) \\
憲法が $\square$ を保証する & 古代(Low)
\end{tabular}

て被験者の反応時間を測定した。

手続き 実験では，まず目的語の空白になっている 単文が視野中央に 3 秒間提示される. 単文が消失する と, 凝視点が 2 秒間提示される. 凝視点が消失した直 後に, 漢字あるいは平仮名の語が右視野かあるいは左 視野に 100 ミリ秒提示される. 被験者に求められるの は，片側視野に提示された語を単文の空白部分に当て はめてみたとき，文として意味を成すかどうかの判断 であった，文と語が適合していれば正のボタンを，文 と語が適合していなければ負のボタンを，できるだけ 速く押すように求めた。正負のボタンの左右の位置 は, 被験者ごとに替えられた。練習試行を 10 回行っ た後に, 本試行を 80 回行った。前半 40 試行の後, 1 分間の休息をとり後半の 40 試行を行った. 正しい反 応の反応時間を記録した。

\section{結果}

条件別の平均反応時間を示したものが, Figure 1 で ある。この資料に対して, 表記形態 $\times$ 具象性 $\times$ 適合 性 $\times$ 視野の 4 要因の分散分析を行った結果は, 次のと おりである. 表記形態 $(F(1,30)=15.21, p<.01)$, 適 合性 $(F(1,30)=58.62, p<.01)$, 具象性 $(F(1,30)=$ $16.39, p<.01)$, 視野 $(F(1,30)=8.16, p<.01)$ の主 効果が，それぞれ有意であった。表記形態では漢字が 仮名よりも反応時間が短く, 適合性では適合文が不適 合文よりも反応時間が短かった。 また，具象性では高 具象性が低具象性よりも反応時間が短く, 視野では右 視野が左視野よりも反応時間が短かった。

交互作用としては, 具象性 $\times$ 視野が有意であった $(F(1,30)=6.40, p<.05)$. この交互作用は高具象語 では視野差がみられないのに，低具象語では左視野よ り右視野の方が有意に反応時間が短いことによってい る $(p<.01)$ 。適合性 $\times$ 視野は有意ではなかったが，そ の傾向がみられた $(F(1,30)=3.63, p<.10)$. ちなみ に, この交互作用の傾向は不適合文では視野差がみら れないのに対し, 適合文では右視野が左視野より反応 時間が短いことによるものであった，また，表記形 
態 $\times$ 適合性が有意であった $(F(1,30)=21.15, p<$ .01)。これは, 適合文では漢字と仮名の反応時間差が 有意でないのに対し，不適合文では仮名が漢字より有 意に反応時間が遅いことによっている $(p<.01)$ 。 な お，表記形態 $\times$ 具象性は有意ではなかった。このこと は，漢字と仮名で具象性による効果が同じであったこ とを示している。

さらに，適合性 $\times$ 具象性 $\times$ 視野が有意であった $(F(1,30)=11.46, p<.01)$. この交互作用は，不適合 文では先の具象性 $\times$ 視野の交互作用が現れていないの に対し，適合文ではこの交互作用がより顕著に現れて いることによる $(F(1,60)=17.75, p<.01)$.すなわ ち, 高具象語では両視野とも反応時間が短く視野差も みられないのに対し，低具象語では左視野より右視野 の方が有意に反応時間が短くなっている.
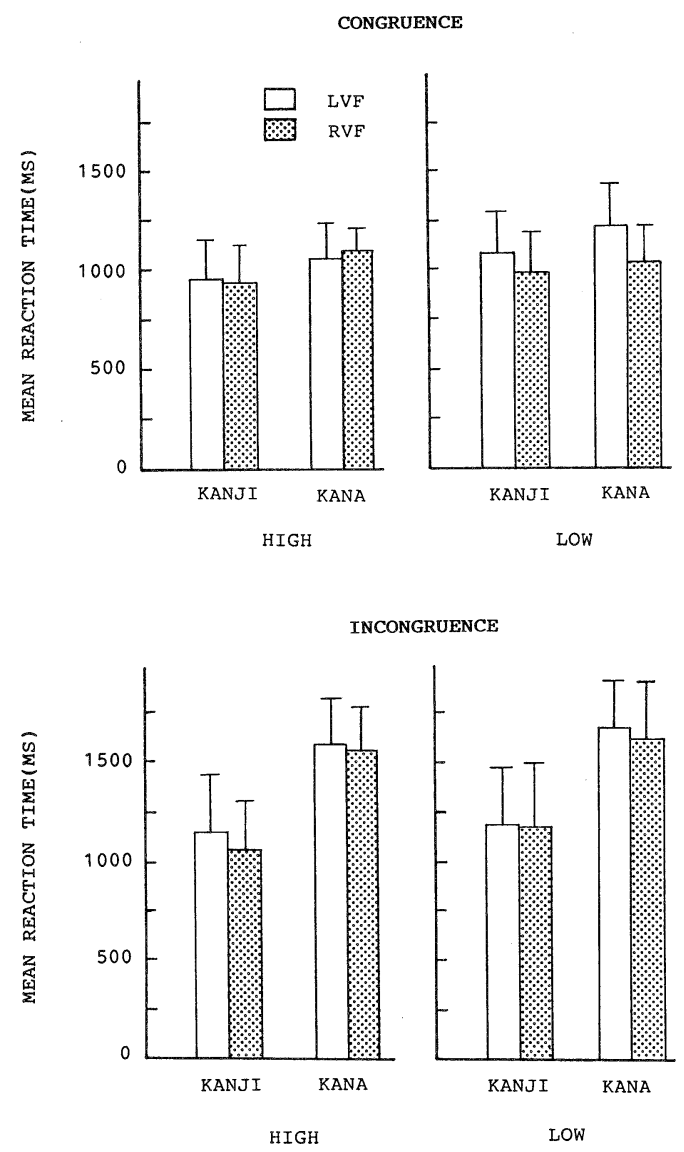

Figure 1. Mean reaction time (ms) as a function of script type, sentence type, concreteness and visual field ( $\mathrm{LVF}=$ left visual field, $\mathrm{RVF}=$ right visual field ; $\mathrm{HIGH}=$ high concrete words, LOW=low concrete words).

\section{考 察}

本研究の主要な結果は，次のとおりである。(1)反 応時間の右視野優位は高具象語ではみられず，低具象 語でのみみられた。さらに，この低具象語の右視野優 位は不適合文ではみられず，適合文でより顕著にみら れた。ただ，表記形態と視野の要因をともに含む交互 作用は全て有意でなかったので，漢字と仮名は前者が 後者より反応時間が速いということはあるけれども， 先の結果について同じ傾向を示していたといえるだろ う。（2）表記形態については，仮名が漢字より遅く適 合判断が行われ，さらにそれは適合文ではなく不適合 文でより著しいことが示された。

まず，本実験の視野要因にかかわる前者(1)の結果 について考察してみよう，漢字と仮名の適合判断は， ともに“適合文”における“低具象語”で右視野が左 視野より有意に速かった。言いかえれば，漢字と仮名 の意味処理に右半球が左半球に劣らないのは, 刺激語 が高具象語の場合と不適合文の場合ということになる (Figure 1). 高具象語で視野差のみられなかったの は，それがイメージ価が高いために心像化能力の優れ ている右半球でも左半球と同じくらいに速く処理でき たからと考えられる。これに対し，低具象語では特に 適合文の場合に左視野の処理が遅くなることによって 右視野との差が出ている。ささらに，左視野では低具象 語が高具象語より有意に処理時間が長いが，右視野で はこの時間差はみられない。これらの結果は，イメー ジ化の困難な低具象語の意味処理が右半球では難しい ことを示している。低具象語は，主として左半球で意 味処理が行われると考えられる，以上の結果は，英語 圏で行われた Ellis \& Shepherd (1974)，Day (1977)な ぞの実験結果と一致しているし，臨床研究の結果とも 一致しているといえる。ここから, 右半球は抽象語の 意味的関係を処理するのは難しいが，具象語の意味的 関係を処理するのは可能であるとする右半球心像化説 を本実験結果は支持していると考えることができる．

不適合文では, 高具象語はもちろん低具象語でも視 野差のみられなかったのはなぜだろうか。この問に答 えるために，ここでまず適合文における判断過程を Collins \& Loftus（1975）の意味記憶の活性化の拡散モ デル (spreading activation model)から考察してみた い。適合文に対する判断では，被験者はまず刺激文か ら予測されるある語 (概念) を内的に活性化して待って いると考えられる。そこに刺激語が提示されて, 刺激 文との適合判断が求められる。活性化されている語と 刺激語が同一であれば，即“適合”の判断が行われる ことになる，仮に同一でなくても，活性化されている 語と意味的に関連のある他の語(概念)もある程度活性 
化されているので，それらを容易に検索することがで き短い時間で適合判断を行うことができる.

不適合文に対する判断でも，被験者は刺激文からあ る語(概念)を予測して待っている。しかし，提示され た刺激語は予測され活性化されている語(概念)とは異 なっているので, 引き続きその他の関連のある語(概 念)を検索していくことになる。しかし，それらの語 (概念)とも一致しないので，被験者は改めて刺激語を 刺激文の文脈に当てはめて，その適合性を判断しなけ ればならない.この検索・判断過程は，適合文のそれ に比べれば明らかに長くかかっている。ゆえに, 刺激 語(特に低具象語)の右半球から左半球への短い転移時 間は結果に反映されず，視野差を生じさせなかったの ではないかと考えられる。

以上の議論から，右半球は語の具象性によってはそ の意味処理が可能であること，そしてこのことは漢 字・仮名ともにいえることが示されたすなおち，右 半球はそのイメージシステムによって, 高具象語の意 味処理を遂行することはできるが，低具象語のそれを 遂行することは難しいことが実証された. 一方, 左半 球は言語システムとイメージシステムの二重システム をもつことによって, 高具象語と低具象語の意味処理 を同じ程度に速く行うことができると考えられる。こ れらのことから, 右半球の言語処理能力について言及 すれば，イメージ化可能な語の意味処理は左半球に劣 らない機能をもっているが，それは左半球の機能を上 回るものではないといえるだろう。

最後に, 漢字が仮名より適合判断が速いという後者 (2)の結果について考察してみよう。この結果は, 漢 字の意味処理が仮名のそれよりも速いことを示唆して いる。これは, 齋藤(1981) および御領 (1987) の結果と 一致している．漢字は，視覚的に提示された語が音韻 的符号化を経ずに直接意味的符号化に至るのに対し， 仮名は視覚的に提示された語が音韻的符号化を経て意 味的符号化に至ると考えられている(御領, 1987；齋 藤，1981)。ここから本実験のように語の読みを求め ないで意味処理を求める課題では，音韻的符号化を経 ずに直接語彙記憶へ接近できる漢字の方が仮名よりも 処理時間が速いということになる．ただ，このことは 適合文ではなく不適合文の場合によりはっきりといえ ることであった。

本実験において，被験者は刺激文が提示されると予 め欠落部分にくるべき語を予測し，それを音韻化ある いは視覚的にイメージ化して次に提示される刺激語を 待っていると考えられる(御領, 1987). したがって, 適合文の場合は刺激語が漢字でもあるいは仮名でも， それが予測した語の音韻的符号あるいは視覚イメージ と合致しているかどうかを判断すればよいわけで, そ
れには漢字と仮名で時間的な差が生じなかったのでは ないかと考えられる。もちろん，適合文の場合でも予 測した語と刺激語が一致しないこともあるが，全く一 致しない不適合文の場合に比べれば不一致の確率は明 らかに低いといえるだろう。一方，不適合文の場合は 予測した語と刺激語が一致しないわけで，被験者は改 めて刺激語を刺激文の文脈に当てはめて，その適合性 を判断し直さなければならない。その際，漢字は直接 語彙記憶に接近して適合性が判断されるが，仮名は音 韻的符号化を経て語彙記憶に接近し, 適合性が判断さ れることになる。この符号化過程の違いから，不適合 文では漢字と仮名の処理時間の差が生じたのではない かと考えられる。

\section{引用文献}

Annett, M. 1967 The binominal distribution of right, mixed and left handedness. Quarterly Journal of Experimental Psychology, 19, 327-333.

Boles, D. B. 1983 Dissociated imageability, concreteness, and familiarity in lateralized word recognition. Memory \& Cognition, 11, 511-519.

Bradshaw, J. L., \& Gates, E. A. 1978 Visual field differences in verbal tasks: Effects of task familiarity and sex of subjects. Brain and Language, 5, 166187.

Code, C. 1987 Language, aphasia, and the right hemisphere. New York: John Wiley \& Sons.

Collins, A. H., \& Loftus, E. F. 1975 A spreading activation theory of semantic processing. Psychological Review, 82, 407-428.

Day, J. 1977 Right-hemisphere language processing in normal right-handers. Journal of Experimental Psychology: Human Perception and Performance, 3, 518-528.

Ellis, H. D., \& Shepherd, J. W. 1974 Recognition of abstract and concrete words presented in left and right visual fields. Journal of Experimental Psychology, 103, 1035-1036.

Elman, J. L., Takahashi, K., \& Tohsaku, Y. 1981 Lateral asymmetries for the identification of concrete and abstract Kanji. Neuropsychologia, 19, 407-412.

Gainotti, G., Caltagirone, C., Miceli, G., \& Masullo, C. 1981 Selective semantic-lexical impairement of language comprehension in right-brain-damaged patients. Brain and Language, 13, 201-211.

Gazzaniga, M. S., Volpe, B. T., Smylie, C. S., Wilson, D.H., \& LeDoux, J.E. 1979 Plasticity in speech organization following commissurotomy. Brain, 102, 805-815.

御領 謙 1987 読むこと 東京大学出版会

Hatta, T. 1977 Lateral recognition of abstract and 
concrete Kanji in Japanese. Perceptual and Motor Skills, 45, 731-734.

Hayashi, R., \& Hatta, T. 1982 Visual field differences in a deeper semantic processing task with Kanji stimuli. Japanese Psychological Research, 24, 111-117.

Joanette, Y., Goulet, P., \& Hannequin, D. 1990 Right hemisphere and verbal communication. New York: Springer-Verlag.

Kinsbourne, M. 1971 The minor cerebral hemisphere as a sourse of aphasic speech. Archives of Neurology, 25, 302-306.

Lesser, R. 1974 Verbal comprehension in aphasia: An English version of three Italian tests. Cortex, 10, 247-263.

Mannhaupt, H. R. 1983 Processing of abstract and concrete nouns in a lateralized memory-search task. Psychological Research, 45, 91-105.

永江誠司 1989 右半球の視覚情報処理 心理学評 論, 32, 387-406.

永江誠司 1991 健常者を対象とした右半球機能研究 杉下守弘(編著) 右半球の神経心理学 朝倉書店 Pp. 242-281.

永江誠司 1992 視野分割研究からみた漢字情報処理 心理学評論, 35, 269-292.

小川嗣夫・稲村義貞 1974 言語材料の諸属性の検討 一一名詞の心像性, 具象性, 有意味度および学習容易 性一一理学研究, 44, 317-327.
Ohnishi, H., \& Hatta, T. 1980 Lateral differences in tachistoscopic recognition of Kanji-pairs with mixed image values. Psychologia, 23, 233-239.

Orenstein, H. B., \& Meighan, W. B. 1976 Recognition of bilaterally presented words varying in concreteness and frequency: Lateral dominance or sequential processing? Bulletin of Psychonomic Society, 7, 179-180.

Paradis, M., Hagiwara, H., \& Hildebrandt, N. 1985 Neurolinguistic aspects of the Japanese writing system. Orlando: Academic Press.

齋藤洋典 1981 漢字と仮名の読みにおける形態的符 号化及び音韻的符号化の検討 心理学研究, 52, 266273.

佐藤敬之輔 1965 文字のデザインシリーズ 3 ひら がな下 丸善

佐藤敬之輔 1976 文字のデザインシリーズ 6 漢字 下 丸善

Shallice, T., \& Warrington, E. K. 1975 Word recognition in a phonemic dyslexic patient. Quarterly Journal of Experimental Psychology, 27, 187-199.

Shanon, B. 1979 Lateralization effects in lexical decision tasks. Brain and Language, 8, 380-387.

島田睦雄・大塚 晃 1981 漢字処理における大脳半 球機能差 心理学評論, 24, 472-489.

- 1992. 6. 3. 受稿, 1993. 11. 6. 受理— 